\title{
Online Learning during the Covid-19 Pandemic: Opportunities and challenges
}

\author{
Athia Fidian ${ }^{1}$, Zulfikar Bagus Pambuko ${ }^{2}$, Lintang Muliawanti ${ }^{3}$, Fitriana Yuliastuti ${ }^{4}$ \\ \{athiafidian@ummgl.ac.id ${ }^{1}$ \} \\ Department of Nursing Science, Universitas Muhammadiyah, Magelang, Indonesia ${ }^{1}$ \\ Department of Islamic Economics Law, Universitas Muhammadiyah, Magelang, Indonesia ${ }^{2}$ \\ Department of Communication Studies, Universitas Muhammadiyah, Magelang, Indonesia ${ }^{3}$ \\ Department of Pharmacy, Universitas Muhammadiyah, Magelang, Indonesia ${ }^{4}$
}

\begin{abstract}
Covid-19 has had a huge impact on various fields, including the education's system. A sudden pandemic situation has an impact on changing the pattern of the learning system. Face-to-face offline learning is turning into distance learning through online learning. Behind the opportunities of online learning, this sudden change of course raises some problems. This article aims to review articles about the challenges and opportunities for online learning during the COVID-19 pandemic. Literature study of several research articles on online learning during the Covid-19 pandemic published in 2020 was conducted as a research method. The results of the review show that there are challenges and opportunities from the learning journey during Covid-19. Opportunities from online learning include flexible learning that can be done anytime and anywhere, not limited to place and time, student ideas that are expressed systematically and explicitly, student freedom to choose courses to follow and which assignments to do first, also learning documentation saved well. However, several challenges were also found, such as unstable internet access, the limitation of internet quota, availability of facilities, creativity of educators, limited participants in the courses, less interactive communication and others.
\end{abstract}

Keywords: Online Learning, Online Learning Opportunities, Online Learning Challenges

\section{Introduction}

The sudden and complete emergence of Covid-19 and the rise of 215 countries in the World, presents its own challenges in the field of Education. Social restrictions and maintaining physical distance are carried out to minimize the spread of covid-19. Severe Acute Respiratory Syndrome Coronavirus-2 (SARS-CoV-2) which causes Coronavirus Disease 2019 (COVID-19) spreads to more than 215 countries and regions including Indonesia. The widespread spread of COVID-19, massif and very rapid impact to all sectors of life is no exception in the field of education [1]. Through the Ministry of Education and Culture the Government has banned faceto-face learning and ordered the online learning [2]. Online learning is one type of learning that requires an internet network and is online based with accessibility, connectivity, flexibility, and the ability to produce various types of learning interactions.

Online learning can be interpreted as a type of learning that uses information technology and done using internet media. Online learning uses Information and Communication 
Technology (ICT) in education to convey information with the aim of improving the learning experience and performance of students where instructors or educators and learners are separated by distance, time, or by both [4]. This definition shows that online learning provides time and space flexibility opportunities through the sophistication of the technology system. Online learning was also chosen as a solution in the pandemic era due to the practicality, effectiveness and efficiency to be implemented remotely. Breaking the chain of spread of Covid19 has forced the face-to-face learning process to become full online learning.

A number of studies have discussed the impact of online learning during pandemics. Online learning drastically and done without careful preparation certainly has a number of challenges as well as opportunities in its implementation. This article aims to review several articles about online learning during the Covid-19 pandemic. This was done to obtain comprehensive information about the opportunities and challenges of online learning during the Covid-19 pandemic.

\section{Method}

This research uses literature review method with some steps such as; identification, collection, selection and analysis of articles related to online learning during pandemics. The systematic review is carried out in several steps; (1) identification, (2) search and collection of journal articles and obtained data from e-database of 25 articles, (3) selection and sorting of articles according to the criteria obtained 10 articles, (4) analysis and presentation of the results of the ten articles [5].

\section{Results and Discussion}

During the covid-19 pandemic educators and learners were forced to use online learning. Educators and learners are required to quickly adapt to a variety of platforms or applications that were not previously familiar to them. Online learning certainly provides a new experience in learning. During the learning and adaptation process, there are many challenges in the journey follow the Table1.

Table 1. Analysis of challenges and opportunities sourced from 10 articles on learning during the covid19 pandemic

\begin{tabular}{|c|c|c|c|c|c|}
\hline No & Name & Journal & Years & Challenge & Opportunities \\
\hline \multirow[t]{5}{*}{1.} & \multirow{5}{*}{$\begin{array}{l}\text { Ali Sadikin } \\
\text { Afreni } \\
\text { Hamidah }\end{array}$} & \multirow[t]{5}{*}{ BIodik } & \multirow[t]{5}{*}{2020} & $\begin{array}{l}\text { availability of internet services } \\
\text { wasteful of quota }\end{array}$ & $\begin{array}{l}\text { A learning which is not } \\
\text { bound by space and time }\end{array}$ \\
\hline & & & & $\begin{array}{l}\text { - } \quad \text { less effective when } \\
\text { more than } 20 \text { learners }\end{array}$ & $\begin{array}{l}\text { The use of some } \\
\text { supporting devices has the }\end{array}$ \\
\hline & & & & $\begin{array}{l}\text { - } \quad \text { the use of the gadget } \\
\text { excessive (uncontrolled)) }\end{array}$ & $\begin{array}{l}\text { advantage of being able to } \\
\text { interact directly between } \\
\text { students and lecturers as }\end{array}$ \\
\hline & & & & Online learning has special & well as teaching materials \\
\hline & & & & $\begin{array}{l}\text { challenges, the location of } \\
\text { students and lecturers who are } \\
\text { separate when carrying out }\end{array}$ & $\begin{array}{l}\text { - Online learning } \\
\text { also has the advantage of }\end{array}$ \\
\hline
\end{tabular}




\begin{tabular}{|c|c|c|c|c|c|}
\hline No & Name & Journal & Years & Challenge & Opportunities \\
\hline & & & & $\begin{array}{l}\text { causes lecturers to be unable to } \\
\text { directly supervise student } \\
\text { activities during the learning } \\
\text { process. } \\
\text { Students have a difficulty in } \\
\text { understanding the lecture } \\
\text { materials given }\end{array}$ & $\begin{array}{l}\text { being able to grow self- } \\
\text { regulated learning }\end{array}$ \\
\hline \multirow[t]{10}{*}{2.} & \multirow{10}{*}{$\begin{array}{l}\text { Elina } \\
\text { Lestariyanti }\end{array}$} & \multirow{10}{*}{$\begin{array}{l}\text { Prakarsa } \\
\text { Paedogogia }\end{array}$} & \multirow[t]{10}{*}{2020} & \multirow{10}{*}{$\begin{array}{l}\text { Characteristics of students } \\
\text { Geographical conditions } \\
\text { Availability of } \\
\text { gadgets/technology devices } \\
\text { Internet quota charges } \\
\text { Educator creativity } \\
\text { Internet affordability }\end{array}$} & Effectiveness \\
\hline & & & & & Flexibility \\
\hline & & & & & $\begin{array}{l}\text { Accommodating Active } \\
\text { and fun learning }\end{array}$ \\
\hline & & & & & Creating a new learning \\
\hline & & & & & atmosphere \\
\hline & & & & & $\begin{array}{l}\text { Improving learning } \\
\text { independence }\end{array}$ \\
\hline & & & & & $\begin{array}{l}\text { Improve learning } \\
\text { motivation }\end{array}$ \\
\hline & & & & & $\begin{array}{l}\text { Increase students' } \\
\text { confidence }\end{array}$ \\
\hline & & & & & Learning new things \\
\hline & & & & & $\begin{array}{l}\text { Improve high-level } \\
\text { thinking skills }\end{array}$ \\
\hline \multirow[t]{4}{*}{3.} & \multirow[t]{4}{*}{$\begin{array}{l}\text { Rodame } \\
\text { Monitorir } \\
\text { Napitupulu }\end{array}$} & \multirow[t]{4}{*}{$\begin{array}{c}\text { Jurnal } \\
\text { Inovasi } \\
\text { Teknologi } \\
\text { Pendidikan }\end{array}$} & \multirow[t]{4}{*}{2020} & \multirow{3}{*}{$\begin{array}{l}\text { cannot obtain learning } \\
\text { materials easily } \\
\text { can't learn the material easily. } \\
\text { Limited devices/facilities } \\
\text { Uneasy of Learning Monitoring }\end{array}$} & $\begin{array}{l}\text { Interactive Learning } \\
\text { Opportunity to respond to } \\
\text { material }\end{array}$ \\
\hline & & & & & - $\quad$ Self-reliance on \\
\hline & & & & & learning \\
\hline & & & & - & \\
\hline \multirow[t]{5}{*}{4.} & \multirow[t]{5}{*}{$\begin{array}{l}\text { Rizqon Halal } \\
\text { Syaj Aji }\end{array}$} & \multirow[t]{5}{*}{ Salam } & \multirow[t]{5}{*}{2020} & $\begin{array}{l}\text { Limitations in Mastering } \\
\text { Information Technology by } \\
\text { educators }\end{array}$ & flexible \\
\hline & & & & $\begin{array}{l}\text { Inadequate Facilities and } \\
\text { Infrastructure }\end{array}$ & \\
\hline & & & & Limited Internet access & \\
\hline & & & & Lack of budget & \\
\hline & & & & - & \\
\hline \multirow[t]{3}{*}{5.} & \multirow{3}{*}{$\begin{array}{l}\text { Fazar } \\
\text { Nuriansyah }\end{array}$} & \multirow{3}{*}{$\begin{array}{l}\text { Pendidikan } \\
\text { Ekonomi } \\
\text { Indonesia }\end{array}$} & \multirow[t]{3}{*}{2020} & Low student understanding & Academic grades increase \\
\hline & & & & Low Motivation & Flexible \\
\hline & & & & & $\begin{array}{l}\text { Increasing learning } \\
\text { creativity }\end{array}$ \\
\hline \multirow[t]{3}{*}{6.} & \multirow{3}{*}{$\begin{array}{l}\text { Luh Sri } \\
\text { Damayanti }\end{array}$} & \multirow[t]{3}{*}{ Journey } & \multirow[t]{3}{*}{2020} & Inequality of internet access & Flexible \\
\hline & & & & Adequate facilities & Minimizing costs in the \\
\hline & & & & Educator's budget & learning process \\
\hline
\end{tabular}




\begin{tabular}{|c|c|c|c|c|c|}
\hline No & Name & Journal & Years & Challenge & Opportunities \\
\hline & & & & $\begin{array}{l}\text { Educator's creativity in creating } \\
\text { media } \\
\text { Types of educator assessments }\end{array}$ & $\begin{array}{l}\text { Providing opportunities } \\
\text { for students to explore } \\
\text { learning topics through } \\
\text { learning resources } \\
\text { available on the internet. } \\
\text { attract students' interest in } \\
\text { learning (engagement) to } \\
\text { foster creativity and } \\
\text { critical thinking skills. }\end{array}$ \\
\hline 7. & $\begin{array}{l}\text { Abd.Syukur, } \\
\text { dkk }\end{array}$ & JPPNu & 2020 & $\begin{array}{l}\text { Internet access } \\
-\quad \text { Educator Creativity }\end{array}$ & $\begin{array}{l}\text { Students are significantly } \\
\text { passionate about the } \\
\text { learning process } \\
\text { Increase student } \\
\text { enthusiasm in responding } \\
\text { to every task/information } \\
\text { Flexible } \\
\text { Effectiveness }\end{array}$ \\
\hline 8. & Suci Ferdiana & $\begin{array}{l}\text { Indonesian } \\
\text { Journal of } \\
\text { Science } \\
\text { Learning }\end{array}$ & 2020 & $\begin{array}{l}\text { Duration limitations } \\
\text { Quota limitations } \\
\text { Less powerful and unstable } \\
\text { internet network } \\
\text { Limited participants } \\
\text { No filtrations of content }\end{array}$ & $\begin{array}{l}\text { facilitating } \\
\text { communication } \\
\text { between lecturers and } \\
\text { students by utilizing } \\
\text { several features to } \\
\text { disseminate learning } \\
\text { information } \\
\text { student ideas will be } \\
\text { revealed systemically } \\
\text { and explicity }\end{array}$ \\
\hline 9. & Asmuni & Paedagogy & 2020 & $\begin{array}{l}\text { Limitations in Mastering } \\
\text { Information Technology by } \\
\text { educators } \\
\text { Internet access Limitation } \\
\text { Supervision from educators to } \\
\text { learners Limitation } \\
\text { Supporting facilities Limitation }\end{array}$ & $\begin{array}{l}\text { Flexible } \\
\text { - } \quad \text { Effectiveness }\end{array}$ \\
\hline 10 & $\begin{array}{l}\text { Niken Bayu } \\
\text { Anggraeni }\end{array}$ & Plancentum & 2020 & $\begin{array}{l}\text { Social media fatigue } \\
\text { Buildup of information/ } \\
\text { concepts } \\
\text { Boredom in students } \\
\text { Students' Stress }\end{array}$ & $\begin{array}{l}\text { Improved literacy } \\
\text { capability } \\
\text { Flexible } \\
\text { Effectiveness } \\
\text { Increase the level of } \\
\text { learning interaction } \\
\text { Make it easier to improve } \\
\text { and store the earning } \\
\text { materials }\end{array}$ \\
\hline
\end{tabular}

Based on the results of the analysis from 10 articles on online learning during the pandemic, there are several challenges such as the availability of internet services, waste of quotas, less effective if more than 20 students, excessive use of gadget (uncontrolled), online learning has 
specific challenges, the location of students and lecturers who are separated while carrying out causes lecturers to be unable to directly supervise student activities during the learning process, and students get difficulty in understanding lecture materials provided online [3], [7]. Other challenges also arise including students' characteristics, geographic conditions, availability of technology gadgets/devices, the cost burden of internet quotas, the creativity of educators, the affordability of internet networks [8], [9], and limited devices/facilities [10]. Limited mastery of information technology by educators, inadequate facilities and infrastructure, limited Internet access, lack of budget provision [11]-[13].

On the other hand, online learning also presents new challenges such as social media fatigue, information/concept build-up, boredom and stress in students [14]. However, online learning also has a positive side that gives rise to learning opportunities that are not tied to space and time, the use of several supporting devices has the advantage of being able to interact directly between students and lecturers as well as teaching materials, online learning also has the advantage of being able to foster self-regulated learning in students [3], [11]. Online learning also has advantages on effectiveness, flexibility, accommodation in learning, creating new learning atmospheres, active and enjoyable learning, improving learning independence, increasing confidence, giving new learning opportunities, improving high-level thinking skills [8], [10], [13]. In addition, online learning provides an opportunity for students to explore learning topics through the learning resources available on the internet, attracting students in engagement so as to foster creativity and critical thinking skills, facilitate communication between lecturers and students by utilizing several features to disseminate learning information, student ideas will be revealed systemically and expressly, improve literacy skills and facilitate the improvement and storage of learning materials [12] [6] [7] [9] [14].

\section{Conclusion}

The COVID-19 pandemic is forcing updates and major changes to the world of education. Face-to-face learning must change with an online learning system. The review from ten research articles related to online learning during the COVID-19 pandemic show a number of opportunities, namely online learning that provides effectiveness, flexibility, accommodation and creates fun active learning and presents a new learning atmosphere. The advantages of online learning also have an impact on the formation of independent characters, confidence, high learning motivation, and improved high-level thinking skills. The learning system that changes rapidly certainly raises challenges in its implementation such as internet access, quota fees, availability and support for technology or gadgets. In addition, the level of teacher creativity, student characteristics, environmental support and geographic conditions are also challenging that need to be considered in order to achieve the best results in the use of online learning.

\section{References}

[1] A. Susilo et al., "Coronavirus Disease 2019: Tinjauan Literatur Terkini," J. Penyakit Dalam Indones., vol. 7, no. 1, p. 45, 2020, doi: 10.7454/jpdi.v7i1.415.

[2] M. P. kebudayaan republik Indonesia, "Surat Edaran Nomor 2 Tahun 2o2a Tentang Pencegahan Dan Pbnanganan Corona Virus T/Seast (Covid-19) Di Kementerian Pendidikan Dan Kebudayaan,” 2, 
2020.

[3] A. H. A. Sadikin, "Pembelajaran Daring di Tengah Wabah Covid-19," J. Ilm. Pendidik. Biol., vol. 6, no. 2, pp. 214-224, 2020, doi: 10.17509/t.v6i2.20887.

[4] K. D. Tantangan and S. Artikel, "Mini-Review Pembelajaran Daring Selama Pandemi Covid-19: Info Artikel," vol. 3, no. 1, pp. 89-96, 2020.

[5] J. C. P. Cardiol, "Systematic Reviews: What They Are, Why They Are Important, and How to Get Involved," The Journal of Clinical and Preventive Cardiology, 2012. .

[6] F. Nuriansyah, "Efektifitas Penggunaan Media Online Dalam Meningkatkan Hasil Belajar Pada Mahasiswa Pendidikan Ekonomi Saat Awal Pandemi Covid-19," J. Pendididikan Ekon. Indones., vol. 1, no. 2, pp. 61-65, 2020.

[7] S. Ferdiana, "Persepsi Mahasiswa tentang Penggunaan Media Daring pada Program Studi S1 Ilmu Gizi Sekolah Tinggi Ilmu Kesehatan Surabaya selama Masa Pandemi Corona Virus Disease (COVID-19),” Indones. J. Sci. Learn., vol. 1, no. 1, pp. 5-12, 2020.

[8] lesrtari; dkk Setyowati, Beradaptasi dengan Perubahan. Dekta Pijar Khatulistiwa, 2020.

[9] A. Asmuni, "Problematika Pembelajaran Daring di Masa Pandemi Covid-19 dan Solusi Pemecahannya," J. Paedagogy, vol. 7, no. 4, pp. 281-288, 2020, doi: 10.33394/jp.v7i4.2941.

[10] R. M. Napitupulu, "Dampak pandemi Covid-19 terhadap kepuasan pembelajaran jarak jauh,” J. Inov. Teknol. Pendidik., vol. 7, no. 1, pp. 23-33, 2020, doi: 10.21831/jitp.v7i1.32771.

[11] R. H. Syah, "Dampak Covid-19 pada Pendidikan di Indonesia: Sekolah, Keterampilan, dan Proses Pembelajaran," SALAM J. Sos. dan Budaya Syar-i, vol. 7, no. 5, pp. 395-402, 2020, doi: 10.15408/sjsbs.v7i5.15314.

[12] L. S. Damayanti, "Implementasi E-Learning Dalam Pembelajaran Bahasa Inggris Di Pendidikan Tinggi Pariwisata Di Bali Selama Pandemi Covid-19," Journey, vol. 2, no. 2, pp. 63-82, 2020.

[13] F. S. Abd. Syakur, Rikhly Faradisy, "Peningkatan Minat Belajar Bahasa Inggris Di Akademi Kebidanan Graha Husada Melalui Aplikasi Google Class Room Pada Masa Pandemi Covid-19 Abd.," J. Pengabdi. dan Pemberdaya. Nusant., vol. 2, no. 1, pp. 88-95, 2020.

[14] N. B. Argaheni, "Sistematik Review: Dampak Perkuliahan Daring Saat Pandemi COVID-19 Terhadap Mahasiswa Indonesia,” PLACENTUM J. Ilm. Kesehat. dan Apl., vol. 8, no. 2, pp. 99 108, 2020, doi: 10.20961/placentum.v8i2.43008. 